\title{
Afordancje dla robotów: krótki przegląd ${ }^{38}$
}

\author{
Thomas E. Horton, Arpan Chakraborty, Robert St. Amant \\ Wydział Informatyki, Uniwersytet stanowy Karoliny Północnej \\ stamant[]ncsu.edu \\ (Tekst oryginalny pt. „Affordances for robots: a brief survey” \\ ukazał się w czasopiśmie Avant, III, 2/2012: 70-84 ${ }^{39}$ )
}

Przekład zaakceptowano: czerwiec 2014; opublikowano: lato 2014.

\begin{abstract}
Abstrakt
Tematem niniejszego artykułu jest wpływ teorii afordancji Gibsona na projektowanie robotów. Teorię afordancji (a ogólniej: podejście ekologiczne do projektowania podmiotów działających [agents ${ }^{40}$ ) wielokrotnie wykorzystywano do stworzenia udanych systemów robotycznych. Przedstawiamy krótki przegląd takich badań w dziedzinie sztucznej inteligencji (dalej: AI). Istnieją jednakże znaczące problemy, które komplikują dyskusję na ten temat; dotyczą one w szczególności wymiany idei pomiędzy badaczami sztucznej inteligencji a psychologami ekologicznymi. Wskazujemy na niektóre z nich, zwłaszcza na brak powszechnie akceptowalnej definicji afordancji i na fundamentalne różnice pomiędzy tymi dziedzinami. Uważamy, że porozumienie między nimi jest możliwe i korzystne dla obu stron, jednak jego osiągnięcie będzie wymagało pewnej elastyczności w traktowaniu percepcji bezpośredniej.

Słowa kluczowe: afordancja; sztuczna inteligencja; psychologia ekologiczna; Gibson; robotyka.
\end{abstract}

\footnotetext{
${ }^{38}$ Robocza wersja przekładu powstała na zajęciach translatoryjnych $\mathrm{z}$ języka angielskiego dla studentów kognitywistyki prowadzonych przez Aleksandrę Derra w roku akademickim 2012/13 w Instytucie Filozofii UMK, w którym wzięły udział następujące osoby: Karolina Finc, Łukasz Goraczewski, Joanna Grzybowska, Janusz Guzowski, Adrianna Heldt, Agnieszka Ignaczewska, Magdalena Kiełbasiewicz, Karolina Kmieciak, Magdalena Łaszewska, Katarzyna Pańczak, Zuzanna Pawłowska, Izabela Postolska, Dagmara Sobczak, Martyna Soborska, Joanna Szczelaszczyk, Kamila Wilczyńska, Malwina Witkowska, Daria Woźniak, Antoni Wójcik. Przekład przejrzała, poprawiła i zredagowała w obecnej postaci Aleksandra Derra.

${ }^{39}$ Przekład publikowany za zgodą właścicieli praw do tekstu.

${ }^{40}$ Podmiot działający bywa określany w literaturze polskojęzycznej także jako agent, aktant, jak również aktor - a z drugiej strony pojęcie agenta służy czasem określeniu systemu takiego jak program komputerowy [przyp. red.].
} 


\section{Wprowadzenie}

Podejście ekologiczne do projektowania robotów może być niezwykle istotne dla badaczy sztucznej inteligencji. Ucieleśnione podmioty usytuowane w środowisku fizycznym mają dostęp do mnóstwa informacji, po prostu postrzegając otaczający ich świat. Wykorzystując relację między podmiotem a jego środowiskiem, projektanci mogą zredukować potrzebę, by podmioty te konstruowały i stabilizowały złożone reprezentacje wewnętrzne. Zamiast tego mogą skupić się na szczegółowych właściwościach bezpośredniego oddziaływania podmiotu na otaczające go środowisko. W rezultacie uzyskują systemy bardziej elastyczne, które są w stanie lepiej reagować na dynamiczne warunki świata rzeczywistego. Wydaje się zatem, że podejście ekologiczne doskonale nadaje się do projektowania ucieleśnionych podmiotów takich jak mobilne roboty autonomiczne, od których wymaga się funkcjonowania w czasie rzeczywistym w złożonym i niestabilnym środowisku.

Jako pierwszy pojęcie afordancji zaproponował psycholog James J. Gibson (1966) i było ono podstawą jego teorii psychologii ekologicznej. Chociaż „afordancja” często nieformalnie opisywana jest jako „możliwość dla działania” [an opportunity for action], wciąż nie istnieje powszechnie akceptowana formalna definicja tego terminu. W pracy The Ecological Approach to Visual Perception Gibson pisze:

Afordancje środowiska są tym, co ono oferuje, zapewnia lub dostarcza zwierzęciu, z korzyścią albo ze stratą dla niego. W słowniku [języka angielskiego] znajdziemy czasownik to afford [z ang. „dostarczyć”, „udostępnić”, „umożliwić”, „pozwolić na coś”], nie znajdziemy natomiast rzeczownika „afordancja”. Wymyśliłem go. Oznacza on dla mnie coś, co odnosi się do zwierzęcia i środowiska w sposób odmienny niż funkcjonujące dotąd terminy. Implikuje wzajemne uzupełnianie się zwierzęcia i środowiska (Gibson 1979:127).

Mimo braku zgody co do tego, czym dokładnie jest afordancja, wielokrotnie próbowano zastosować pojęcia ekologiczne w projektowaniu podmiotów sztucznych. W wielu przypadkach badacze sztucznej inteligencji czerpali bezpośrednią inspirację z psychologii ekologicznej, w innych zaś formułowali niezależnie teorie, które pomimo swojej odmienności pod pewnymi względami zgadzały się na wiele sposobów z propozycjami Gibsona.

Często widać jednak, że psychologowie i badacze AI bardzo różnie podchodzą do rozumienia afordancji oraz sposobu używania ich przez podmioty, zarówno organiczne, jak i sztuczne. W związku z tym cel tego artykułu jest dwojaki. Po pierwsze chcemy przedstawić krótki przegląd dotychczasowych prac w dziedzinie sztucznej inteligencji, aby skorzystali na tym wszyscy badacze (część druga). Po drugie - w trzeciej części chcemy przyjrzeć się wybranym zasadniczym problemom, które mogą skomplikować próby pogodzenia ujęć formułowanych w psychologii ekologicznej z tymi postulowanymi w sztucznej inteligencji, co może utrudnić komunikację pomiędzy tymi dwiema dziedzi- 
nami. Dotyczy to zwłaszcza roli, jaką odgrywa teoria percepcji bezpośredniej Gibsona. Czwarta część to podsumowanie, w którym spekulujemy na temat przyszłości teorii sztucznej inteligencji, które opierałaby się na pojęciu afordancji.

\section{Podejście ekologiczne w sztucznej inteligencji}

W projektowaniu sztucznych podmiotów pojawiło się kilka udanych modeli kontroli i koordynacji percepcji oraz działania. Łączy je pewna wspólna właściwość: jawne położenie nacisku na wykorzystywanie środowiska i wzajemnego oddziaływania między nim a podmiotem, co redukuje złożoność reprezentacji i rozumowania. Właściwość ta ma podstawę w ekologicznej koncepcji podmiotu - który jest bytem ucieleśnionym w świecie bogatym w obserwowalne wskazówki mogące pomóc kierować jego zachowaniem. Jak podsumował to Brooks: „świat jest swoim najlepszym modelem” (Brooks 1990: 5).

Rozpoczniemy od krótkiego przeglądu literatury z zakresu sztucznej inteligencji, koncentrując się na paradygmatach projektowania podmiotu, które zawierają elementy podejścia ekologicznego. Choć badacze AI nie zawsze dokonywali tych samych wyborów co Gibson, znaczna część tego, co opiszemy, wyda się znajoma czytelnikowi oswojonemu z podstawami psychologii ekologicznej.

\subsection{Paradygmaty projektowania podmiotu}

Posługiwanie się zmysłami, planowanie (lub rozumowanie) i działanie to trzy główne procesy, o które musi zadbać podmiot. W tradycyjnych systemach deliberatywnych (Maes 1991) modeluje się je jako komponenty odrębne, które stają się aktywne w cyklach o liniowej sekwencji: zmyst-plan-działanie (Gat 1998). Metodologia ta pozwoliła na w dużej mierze niezależne opracowanie tych trzech elementów, zwłaszcza niezależnym od dziedziny planistom, którzy byli w stanie wykorzystać postępy w ogólnym rozwiązywaniu problemów [general problem-solving] ${ }^{41}$ i w rozumowaniu formalno-logicznym (Fikes i in. 1972; Newell i Simon 1963; Sacerdoti 1974).

Taki sposób zorganizowania pociąga za sobą dwie ważne konsekwencje. Po pierwsze rozdzielenie powyższych procesów sprawia, że potrzebujemy abstrakcyjnej wewnętrznej reprezentacji środowiska (jego całości lub części), aby przekazać informacje z komponentu percepcyjnego do systemu planowania.

\footnotetext{
${ }^{41}$ Nawiązanie do tak zwanego General Problem Solver (GPS) czyli „Ogólnego rozwiązywacza problemów”, programu komputerowego skonstruowanego przez Herberta Simona i Allena Newella w 1957 roku. Pozwalał on rozwiązywać niektóre problemy, które dawały się sformalizować, niemniej nie nadawał się zbytnio do rozwiązywaniu problemów realnych [przy.tłum].
} 
Ten pośredniczący „bufor” może potencjalnie odłączyć realny stan środowiska od przekonań podmiotu. Po drugie niepowodzenie planu traktuje się jako wyjątek, z którym zazwyczaj radzimy sobie, ponownie explicite planując. Wszystko to w połączeniu z nieodłączną niepewnością oraz nieprzewidywalnością świata realnego może ograniczyć wszechstronność fizycznie istniejących robotów. Badacze podjęli te wyzwania, wprowadzając udoskonalenia takie jak modelowanie niepewności i niezdeterminowania (Bacchus i in. 1999) oraz dynamicznego planowania (Stentz 1995; Zilberstein i Russell 1993).

$\mathrm{W}$ ujęciu ekologicznym mamy do czynienia z zupełnie odmiennym podejściem do projektowania podmiotu, gdzie opieramy się w przeważającej mierze na prostych, wydajnych komponentach percepcyjnych (w przeciwieństwie do złożonych konstrukcji umysłowych) i powszechnych mechanizmach leżących u podstaw używania zmysłów, rozumowania i działania (Brooks 1986). Planowanie i działanie $w$ takich systemach są zwykle procesem ściśle powiązanym, w którym podmiot nieprzerwanie na nowo oblicza najlepszy sposób wykonania krótkoterminowego działania, jednocześnie wykonując zadanie bieżące. Zmniejsza to zależność od stanu sterowania [control state] rejestrującego postęp podmiotu w wykonywaniu sekwencji działań, które mogą opierać się na potencjalnie nieaktualnych informacjach.

Podmiot świadomy swojego otoczenia może wykazać się elastycznością, kiedy zmieniają się warunki, jednocześnie zachowując się w sposób złożony. Chapman (1991) poprzez użycie środowiska symulowanego pokazuje, jak zasady podejścia ekologicznego mogą pomóc podmiotowi przerwać rutynę, która nie jest już właściwa, ponowić nieudane działania, tymczasowo zawiesić jedno zadanie na rzecz innego, zmienić kolejność wykonywania zadań i łączyć je, aby osiągnąć jednocześnie kilka celów. Podobne własności pojawiły się u wielu fizycznie istniejących, zautomatyzowanych systemów, które opierają się na odmiennych metodologiach i wzorcach projektowych, niemniej zgodnych z perspektywą ekologiczną.

Percepcja nastawiona na działanie lub oparta na zadaniach (Arkin 1990) to ujęcia, których robotycy używają do radzenia sobie $\mathrm{z}$ nieodłączną niepewnością $\mathrm{w}$ świecie rzeczywistym. Wiedza na temat obecnej sytuacji robotów, ich zamierzonego działania i spodziewanych perceptów może pomóc wprowadzić dostateczną ilość uwarunkowań, by percepcja była trafna oraz dała się modelować. Zwolennik powyższego podejścia, Ballard (1991), posługując się paradygmatem „Animate Vision” [ruchomego widzenia] przekonuje, że zdolność do kontroli wizualnego bodźca wejściowego [input] (w szczególności spojrzenia) umożliwia wykorzystanie kontekstu środowiskowego do uproszczenia zadań takich jak rozpoznawanie obiektów i wizualne wspomaganie. Powtarzają to Brooks i Stein (1994) oraz potwierdzają niektóre późniejsze systemy (Gould i in. 2007; Kuniyoshi i in. 1996; Scassellati 1999). 
Metodologię nakierowaną na zadanie można uogólnić w taki sposób, by objęła inne aspekty bieżącej sytuacji podmiotu. Chapman (1991) i Agre (1987) wskazują na to, jak afordancje środowiska można scharakteryzować w ramach ogólnej teorii działania usytuowanego, która jest jednym ze sposobów konceptualizowania elementów środowiskowych. Pokazują oni również, jak polecenia wydawane systemom sztucznym mogą odnosić się do funkcjonalnych jednostek indeksowania, to jest do wskaźników obiektów świata rzeczywistego, określonych bezpośrednio dzięki ich cechom istotnym w danym kontekście sytuacyjnym, zamiast nieograniczonego, ogólnego rozpoznawania. Właściwości obiektów-kandydatów wraz ze ich afordancjami pomagają wyeliminować wieloznaczność instrukcji. Podobnie na przykład [słowo] „to” w [wyrażeniu] „podnieś to” może odnosić się tylko do obiektów, które da się podnieść.

Robotyka skupiła się także na innych elementach pochodzących ze środowiska. W swojej pracy nad humanoidalnym robotem Cog Brooks i inni (1997) podkreślali konieczność uwzględnienia formy cielesnej w tworzeniu systemów reprezentacyjnych oraz systemów wnioskowania, które kontrolują roboty. Matarić (1994, 1997) w robotyce opartej na zachowaniu podkreślał ważność uczenia się w wyborze zachowania oraz zauważył, że polega ono na uczeniu się warunków wstępnych danego zachowania. Co więcej, wnioskowanie na temat zachowań - szczególnie w kontekście planowania wymaga, aby zachowania były związane $\mathrm{z}$ własnościami lub stanami środowiska. Taki sposób rozumowania pozwala robotom „myśleć w sposób, w jaki działają” (Matarić 2002).

Wielu naukowców zastosowało pojęcie przepływu optycznego [optic flow] Gibsona do robotycznych podmiotów autonomicznych. Na przykład Duchon i inni (1998) opisują projekt robotów mobilnych, które wykorzystują techniki przepływu optycznego nie tylko do omijania przeszkód, ale także by realizować zachowania typu drapieżnik-ofiara, które pozwalają jednemu podmiotowi ścigać drugi, gdy ten próbuje uciekać.

\subsection{Podejście oparte na afordancji}

Większość badań przytoczonych do tej pory nie odnosi się bezpośrednio do Gibsonowskich afordancji. W tej części rozważymy przykłady z literatury na temat sztucznej inteligencji, których uwaga koncentruje się w szczególności na podmiotach zaprojektowanych tak, by wykorzystywać afordancje. Ogólnie rzecz ujmując, celem jest zastosowanie pojęć z psychologii ekologicznej, aby rozwinąć sprawniejsze podmioty, mimo że mogą pojawić się pewne wątpliwości co do tego, na ile podawane wyniki są zbieżne z podejściem Gibsona. 
Najnowsze prace w zakresie sztucznej inteligencji doprowadziły do opracowania robotów zdolnych do eksploatowania afordancji, by wspomóc rozmaite zachowania, włączając $w$ to przechodzenie obok obiektu i omijanie go (Çakmack i in. 2007; Erdemir i in. 2008a, 2008b; Murphy 1999; Şahin i in. 2007; Sun $i$ in. 2010; Ugur i in. 2009, 2010), chwytanie go (Cos-Aguilera i in. 2003a, 2003b, 2004; Detry i in. 2009, 2010, 2011; Kraft i in. 2009; Yürüten i in. 2012) oraz manipulowanie nim poprzez szturchanie, pchanie, ciągnięcie, obracanie i podnoszenie (Atil i in. 2010; Dag i in. 2010; Fitzpatrick i in. 2003; Fritz i in. 2006a, 2006b; Rome i in. 2008; Ugur i in. 2011, Sun i in. 2010; Yürüten i in. 2012).

Interesuje nas zasadniczo projektowanie podmiotów zdolnych do użytkowania afordancji narzędzi. Wykorzystywanie narzędzi jest pokrótce rozważane przez Gibsona (1979) i Michaelsa (2003) i było ostatnio badane przez Jacqueta oraz jego współpracowników (2012), ale nie spotkało się z dużym zainteresowaniem ze strony psychologii ekologicznej. Zbiór prac na temat afordancji w AI jest niewielki, ale stale się powiększa (np. Guerin i in. 2012), znajdziemy w nim studia nad afordancjami narzędzi, które służą do zdalnego manipulowania celami (Jain i Inamura 2011; Sinapov i Stoytchev 2007, 2008; Stoytchev 2005, 2008; Wood i in. 2005) oraz wykorzystania obiektów zewnętrznych jako pojemników (Griffith i in. 2012a, 2012b). Najnowsze badania w naszym laboratorium skupiły się na systemach służących do rozpoznawania afordancji niższego rzędu [low-level affordances], które ułatwiają bardziej złożone zachowania, jak posługiwanie się narzędziami, w przypadku których mamy fizyczne sprzężenia pomiędzy śrubokrętem a otworem na śrubę, czy między kluczem nasadowym a główką śruby (Horton i in. 2008, 2011).

Większość systemów opartych na afordancjach używa [modelu] podmiotów ucieleśnionych $\mathrm{w}$ celu kontroli fizycznie istniejących robotów; inne stosują środowiska symulowane lub używają symulacji w połączeniu z interakcją fizyczną (Cos-Aguilera i in. 2003a, 2003b, 2004; Erdemir i in. 2008a, 2008b; Fritz i in. 2006a, 2006b; Jain i Inamura 2011; Rome i in. 2008; Şahin i in. 2007; Sinapov i Stoytchev 2007, 2008; Ugur 2011).

Podobnie jak w przypadku większości badań w psychologii ekologicznej, większość tych systemów koncentruje się na percepcji wizualnej, wykorzystując kamery fizycznie istniejące lub wirtualne. Niemniej kilka systemów stosuje dodatkowe rodzaje informacji wejściowych [input]. Przykładowo Atil i inni (2010), Griffith (2012a, 2012b), Murphy (1999), Şahin i inni (2007) oraz Ugur i inni (2009, 2010, 2011) używają odległościomierzy [range finders] do dokładnego szacowania, a system opisany przez Griffina (2012a, 2012b) korzysta dodatkowo z akustycznej informacji zwrotnej. U Atila i innych (2010) oraz Yürütena i innych (2012) systemy dodatkowo posługują się na wejściu etykietami przypisanymi przez ludzi do obiektów i działań.

Niezależnie od tego, czy są to systemy fizyczne, czy symulowane, wspólne jest im podobne podejście do zachowań poszukiwawczych czy do etapów „gawo- 
rzenia" [babbling], kiedy podmiot zwyczajnie testuje działanie bez określonego celu, żeby obserwować jego skutki (jeśli wystąpią) w środowisku. Dzięki temu podmiot jest w stanie nauczyć się afordancji swojego środowiska w dużej mierze niezależnie. Jednak afordancje, które może odkryć, nie zależą jedynie od jego umiejętności fizycznych i zdolności percepcyjnych, ale także od typu zachowań poszukiwawczych, do których go zaprogramowano (Stoytchev 2005).

Możliwe, że najistotniejsze z punktu widzenia naszych rozważań jest niemal powszechnie podzielane przekonanie, że afordancje są relacjami wewnętrznymi pomiędzy zewnętrznymi obiektami a działaniami samego podmiotu. Perspektywa ta nie zgadza się z podejściem proponowanym przez Gibsona. Na przykład Vera i Simon (1993) proponują odmienną interpretację afordancji od powszechnie utrzymywanej $\mathrm{w}$ psychologii ekologicznej, formułowaną $\mathrm{w}$ ramach stanowiska, które Chemero i Turvey (2007) określają jako „reprezentacjonalistyczne” (w opozycji do „Gibsonowskiego”). Odpowiadając zwolennikom działania usytuowanego, poglądu na temat poznania i sztucznej inteligencji podobnego do psychologii ekologicznej, przekonują oni, że jego zwolennicy w dużej mierze nie doceniają złożoności percepcji. Vera i Simon sugerują raczej, że pozorna prostota percepcji jest wynikiem złożonych mechanizmów kodowania skomplikowanych wzorców bodźców w środowisku. W tej perspektywie afordancje są wewnętrznymi reprezentacjami funkcjonalnymi, które powstają w wyniku tego procesu kodowania; afordancje są w "głowie” (Vera i Simon 1993: 21).

Şahin i inni (2007) oraz Ugur i inni (2009) wraz ze swoimi współpracownikami niedawno sformalizowali ten punkt widzenia. Rozpoczęli swoją formalizację afordancji od tego, że zaobserwowali, iż swoistą interakcję ze środowiskiem można reprezentować za pomocą relacji o formie (efekt (byt [entity], zachowanie)), gdzie „byt” jest stanem środowiska, „zachowanie” - rodzajem działania, które podejmuje podmiot w środowisku, a „efekt” - rezultatem. Pojedyncza interakcja to wystąpienie [pojedynczego przypadku] tej relacji. Wielokrotne interakcje można uogólnić tak, że podmiot będzie zdolny do przewidywania swoich zachowań w zależności od różnych elementów środowiska. Dlatego afordancje można potraktować jako relacje rodzajowe ze zdolnościami przewidywania.

Co więcej, zauważyliśmy, że niektóre z systemów, o których wspominaliśmy, zaprojektowano dokładnie po to, by obiekty i działania przypisywać do określonych kategorii (np. Sun i in. 2010). Gibson (1979) zwraca uwagę, że należy odrzucić potrzebę kategoryzowania w percepcji afordancji, co wraz z przekonaniem, że afordancje są relacjami wewnętrznymi, stanowi kolejne punkty sporu między zwolennikami AI a psychologii ekologicznej.

Badania, które tutaj przywołujemy, ilustrują [pogląd], że podejścia oparte na afordancjach skutecznie stosowano do [rozwiązania] licznych problemów 
w sztucznej inteligencji. Jednak jej badacze często posługiwali się własnymi interpretacjami pojęć ekologicznych takich jak afordancje - interpretacjami, które czasami znacząco różnią się od tych formułowanych w psychologii ekologicznej.

W projektowaniu podmiotów sztucznych nie wykorzystano jeszcze wielu możliwości kryjących się $\mathrm{w}$ teoriach opartych na afordancjach. Dlatego w licznych spośród rozważanych dotąd zastosowań skupiano się na podstawowych zadaniach, takich jak na przykład omijanie przeszkód, przesuwanie obiektów. Przewidujemy pojawienie się nowych zastosowań w miarę rozwoju robotyki, opracowującej roboty o coraz większych umiejętnościach, zdolnych do używania narzędzi czy też do innych bardziej złożonych zachowań.

\section{Kwestie otwarte}

W tej części zaczniemy od krótkiego omówienia jednego z podstawowych zagadnień, z którym borykają się badacze sztucznej inteligencji, rozważając pojęcie afordancji. Mianowicie z tym, co konkretnie dla psychologów ekologicznych oznacza „afordancja”. Następnie wskażemy na kilka dodatkowych problemów, które mogą pojawić się, gdy próbujemy pogodzić podejście ekologiczne z wymogami implementacji sztucznego podmiotu.

\subsection{Definiowanie „afordancji”}

Nieformalnie afordancje określa się jako „możliwości dla działania”. Jednak wydaje się, że nawet wśród psychologów ekologicznych nie ma zgody co do bardziej formalnego rozumienia tego pojęcia. Idee samego Gibsona na ten temat ewoluowały na przestrzeni dekad. Na przykład Jones (2003), kreśląc pochodzenie tego pojęcia, odwołuje do prac Gibsona z lat trzydziestych XX wieku i przekonuje, że jego poglądy zmieniały się do czasu jego śmierci w 1979 roku.

Gibson najszerzej pisał o afordancjach w książce The Ecological Approach to Visual Perception (1979). Nakreśla w niej genezę tego pojęcia i proponuje wiele przykładów, ale nie przedstawia konkretnej definicji, a jego wyjaśnienia są często bardzo mgliste. Na przykład w dodatku do opisu zawartego na początku wprowadzenia Gibson pisze:

Ważny fakt dotyczący afordancji środowiska jest taki, że są one w pewnym sensie obiektywne, realne i fizyczne, w przeciwieństwie do wartości i znaczeń, o których często przyjmuje się, że są subiektywne, fenomenalne i mentalne. Jednakże afordancja nie jest ani własnością obiektywną, ani subiektywną, albo inaczej: jest zarówno jednym, jak i drugim. Afordancja wykracza poza rozróżnienie subiektywny-obiektywny i pomaga nam zrozumieć, że jest ono niewłaściwe. Jest w równym stopniu czymś, co zaszło w środowisku, i czymś, co prze- 
jawia się w zachowaniu. Czymś zarówno fizycznym, jak i psychicznym, ale jednocześnie żadnym z nich. Afordancja wskazuje zarówno na środowisko, jak i obserwatora (Gibson 1979: 129).

Mimo tego, że nie mamy tu jednego jasnego, uściślającego twierdzenia, niektóre uwagi Gibsona pomagają objaśnić jego sposób myślenia. Jak podsumowali McGrenere i Ho (2000), Gibson określa trzy podstawowe właściwości afordancji: afordancja jest uzależniona od zdolności konkretnego aktora; istnienie afordancji jest niezależne od zdolności jej postrzegania przez aktora; afordancja nie zmienia się wraz ze zmianą potrzeb i celów aktora. Pomimo iż powyższe podsumowanie pomaga wyjaśnić stanowisko Gibsona, nadal wiele kwestii pozostaje otwartych na interpretację.

Co więcej, Gibsonowskie opisy afordancji wydają się niezwykle rozległe, znajdziemy w nich takie przykłady jak jedzenie oferujące [affording], pożywienie i urwisko oferujące [affording], niebezpieczeństwo oraz przykłady bardziej konkretne i znane, takie jak młotek oferujący [affording] uderzenie. Być może takie ogólnikowe podejście jest czasami pożądane (Stoffregen 2004), sprawia jednak, że trudno jest ocenić omawiane pojęcie empirycznie. Opisom Gibsona brakuje mocy prognostycznej, mówią niewiele o tym, jak afordancje wyłaniają się z własności fizycznych, jak organizm może rozpoznać afordancje, by je wykorzystać - są to kluczowe problemy w opracowywaniu sztucznego podmiotu, który kieruje się afordancjami.

W kolejnych dekadach po śmierci Gibsona w psychologii ekologicznej debatowano nad tym, jak najtrafniej zdefiniować pojęcie afordancji. Dyskusje były złożone, różni autorzy proponowali wiele interpretacji i definicji, stąd powstało kilka zasadniczych punktów spornych. Na przykład co do tego, czy afordancje są własnościami środowiska, czy aspektami połączonego systemu zwierzę-środowisko; czy afordancje są własnościami dyspozycyjnymi, czy relacjami; czy afordancje są czymś, co dopełnia „efektywność” organizmu, czy odnoszą się do wielkości jego ciała. Nie ma tu wystarczająco dużo miejsca na wnikanie w szczegóły, z którymi można zapoznać się na przykład w analizie Chemero (2003).

Co więcej, Şahin i inni (2007) sugerują, że kolejnym źródłem nieporozumienia jest to, że afordancje mogą być postrzegane $\mathrm{z}$ trzech różnych perspektyw: podmiotu, środowiska lub zewnętrznego obserwatora, co dodatkowo komplikuje próby uzgodnienia definicji.

Niestety, nadal brakuje jednej i powszechnie akceptowanej formalnej definicji „afordancji”. Podjęto próby, by taką podać (np. Chemero 2003; Heft 2003; Jones 2003; Michaels 2003; Stoffregen 2003), ale były to tylko kolejne głosy w debacie. Porozumienie nie zostało osiągnięte. Często powyższe próby zdefiniowania są podobnie problematyczne jak oryginalne opisy Gibsona; są bardzo szerokie i brakuje im wskazówek heurystycznych (Kirlik 2004). 


\subsection{Czy podejścia psychologiczne i obliczeniowe są ze sobą zgodne?}

Częściowo ze względu na brak jednej, przyjętej definicji możliwe jest, że kiedy psychologowie ekologiczni i badacze sztucznej inteligencji mówią o afordancjach, często odnoszą się do bardzo różnych rzeczy (Şahin i in. 2007). Rozbieżność ta może wynikać stąd, że obie społeczności stawiają sobie różne cele: psychologowie skupiają się na opisywaniu zachowań, a inżynierowie AI na wdrażaniu systemów ${ }^{42}$.

Wydaje się, że panuje powszechna zgoda co do tego, że afordancje są „relacjami”, ale także tutaj psychologowie i badacze AI mogą używać tego terminu odmiennie. Na ogół naukowcom $\mathrm{w}$ obu dziedzinach odpowiada używanie pojęcia afordancji rozumianych jako relacje pomiędzy fizycznymi właściwościami podmiotu a środowiskiem. Postrzegane w ten sposób są one relacjami zewnętrznymi $\mathrm{w}$ odróżnieniu od wewnętrznych konstrukcji umysłowych, a kluczowe pytanie brzmi tutaj: czy afordancje istnieją fizycznie, to znaczy: czy to właśnie środowisko pozwala podmiotowi działać w określony sposób?

Oprócz postrzegania afordancji jako relacji zewnętrznych, badacze AI mają skłonność do odwoływania się do nich jako wewnętrznych reprezentacji umysłowych (np. Vera i Simon 1993). Tutaj także pojawiają się spory w dyskusjach pomiędzy tymi dwiema dziedzinami. W tym miejscu kluczowe pytanie nie dotyczy tego, czy afordancja istnieje w środowisku, czy nie, ale dotyczy [rodzaju] mechanizmu, dzięki któremu podmiot ją postrzega. Fizyczna afordancja składa się z właściwości lub zestawu właściwości, które mogą być odbierane zmysłowo. W powszechnie przyjmowanym ujęciu AI podmiot łączy te percepty z określonym przebiegiem działania, prawdopodobnie zapośredniczonego przez aktualny stan podmiotu (na przykład jego zestaw celów). Dlatego też badacze AI często traktują afordancję jako relację między rozpoznaniem jakiejś własności fizycznej a powiązaną z nią reakcją. Psychologowie ekologiczni mogą jednak przeciwstawiać się użyciu słowa „afordancja” do opisania takich reprezentacji wewnętrznych, które zostały odrzucone przez Gibsona (np. Chemero i Turvey 2007 w odpowiedzi na Şahin i in. 2007). Zauważmy, że ten punkt widzenia niekoniecznie kłóci się z postrzeganiem afordancji jako relacji fizycznych, mamy tu raczej do czynienia z dodatkowym zastosowaniem tego terminu, choć być może inny wybór słowa byłby mniej kontrowersyjny.

\footnotetext{
${ }^{42}$ Co więcej, odmiennie używany termin „afordancja” funkcjonuje w dziedzinie ergonomii i w badaniach nad interakcją między człowiekiem a robotem (Norman 1988, 1999), znacząco różniąc się od użycia zarówno w psychologii ekologicznej, jak i w sztucznej inteligencji, wskazując na priorytety przyjęte przez tych, którzy się nim posługują.
} 


\subsection{Rola percepcji bezpośredniej}

Problem postrzegania afordancji odwołuje do kolejnego, blisko powiązanego punktu sporu, jakim jest rola percepcji bezpośredniej. Chemero i Turvey (2007) traktują afordancje i percepcję bezpośrednią jako dwa elementy, które definiują stanowisko ekologiczne.

W percepcji bezpośredniej afordancje są postrzegane poprzez „niezmienniki” wyłowione wprost ze strumienia optycznego. Jej zwolennicy twierdzą, że nie ma potrzeby, by wewnętrzne reprezentacje umysłowe pośredniczyły w procesie percepcji. Dlatego przykłady z AI, które traktują afordancje jako reprezentacje wewnętrzne (jak opisane powyżej), mogą być kontrowersyjne, bo są niezgodne z pojęciem percepcji bezpośredniej.

Często przytaczanym przykładem percepcji bezpośredniej jest zastosowanie przepływu optycznego do nawigacji. Rzeczywiście, istnieją przekonujące świadectwa, które sugerują, że organizmy biologiczne wykorzystują strumień optyczny (np. Srinivasan i Zhang 2004). Ponadto przeprowadzono udane próby zastosowania go w projektowaniu podmiotów sztucznych (np. Duchon i in. 1998).

Niemniej w literaturze przedmiotu wyczerpująco pokazano, że percepcja bezpośrednia jest uproszczeniem rozważanej problematyki. Na przykład Marr (1982), chwaląc ogólne podejście Gibsona, przekonuje, że istnieją dwa zasadnicze niedociągnięcia $\mathrm{w}$ jego teorii związane $\mathrm{z}$ tym, że skupia się on na percepcji bezpośredniej niezmienników. Po pierwsze, w przeciwieństwie do tego, co twierdzi Gibson, wykrywanie fizycznych niezmienników jest problemem przetwarzania informacji, a po drugie Gibson znacząco nie docenia problematyczności tego procesu (Marr 1982: 29-30).

Ullman (1980) przeprowadza obszerną krytykę teorii leżącej u podstaw percepcji bezpośredniej z perspektywy kognitywistycznej. Przekonuje on, że procesy, które Gibson uważa za bezpośrednie, można dalej rozłożyć na prostsze procesy percepcyjne, i stawia wniosek, by odwoływanie do wyjaśnień bezpośrednich uznawać za „ostateczność”. Gyr (1972) podsumowuje szereg badań empirycznych, które podają w wątpliwość twierdzenia [teorii] percepcji bezpośredniej, podkreślając, że stan podmiotu odgrywa kluczową rolę w percepcji, ponieważ dookreśla, jaka część strumienia optycznego jest istotna w danym momencie i jaka będzie jej interpretacja. Fodor i Pylyshyn (1981) twierdzą, że właściwości dostępne w strumieniu optycznym, które potencjalnie mogłyby być wychwycone bezpośrednio, same nie wystarczają do pełnego wyjaśnienia percepcji bez pośrednictwa pamięci, wnioskowania lub innych procesów psychologicznych zależących od reprezentacji. Podsumowując powyższe rozważania, można powiedzieć, że akt percepcji w dużym stopniu zależy od wewnętrznych stanów umysłowych, reprezentacji i obliczeń. 
Nie oznacza to, że powinniśmy zrezygnować z upraszczania projektowania podmiotu, podejmując próby minimalizowania konieczności [uwzględnienia] złożonych reprezentacji, ale sugeruje, że nie uda się ich całkowicie wyeliminować. Z pewnością z punktu widzenia praktyki wydaje się, że nie ma oczywistego sposobu implementowania zachowań bardziej złożonych (jak na przykład używania narzędzi), które nie wiązałyby się z jakiegoś rodzaju reprezentacją. Należy pamiętać, że naszym celem jako badaczy AI jest zazwyczaj kopiowanie zachowań, które mogą, ale nie muszą szczegółowo powielać modele podstawowych mechanizmów wykorzystywanych przez systemy biologiczne. Nawet jeśli organizmy biologiczne wykorzystują formę percepcji bezpośredniej, może okazać się, że odtwarzanie tych mechanizmów przez podmioty sztuczne jest niepraktyczne lub nawet niewskazane (weźmy po uwagę, że istnieją ogromne różnice w bazowym „hardware” pomiędzy neuronami w mózgu biologicznym a tranzystorami mikroprocesora). Przy podejmowaniu decyzji, jakie modele zastosować w konstrukcji sztucznego podmiotu, należy uwzględnić wszystko: łatwość implementacji, szybkość realizacji oraz ostateczną wydajność systemu. Zatem wierność odtwarzania zastosowanego modelu zależy od kilku czynników, w tym od tego, jak dobrze rozumiemy mechanizmy biologiczne, jak łatwo mogę być one powielane za pomocą dostępnego sprzętu i oprogramowania, a także od przyjętych celów badawczych.

Niemniej jednak percepcja bezpośrednia pozostaje kluczowym elementem perspektywy psychologii ekologicznej. Dlatego związane z nią problemy mogą być najbardziej kontrowersyjnym punktem dyskusji prowadzonej między rozważanymi dziedzinami. Na przykład Chemero i Turvey (2007) stwierdzają, odpowiadając Şahinowi i jego współpracownikom (2007), że pomimo prowadzenia sporu o naturę afordancji wszyscy psychologowie ekologiczni „upierają się przy takim rozumieniu afordancji, by uwzględniać kolejny główny składnik Gibsonowskiej psychologii ekologicznej, jaką jest [percepcja bezpośrednia]" (Chemero i Turvey 2007: 474). Wydaje się, że również Michaels i Carello (1981) odrzucają możliwość pogodzenia stanowiska [związanego z percepcją bezpośrednią] z podejściem obliczeniowym/reprezentacyjnym. Rzeczywiście czasami literatura psychologii ekologicznej wydaje się nieprzychylna podejściu, które kwestionuje rolę tej percepcji.

\section{Podsumowanie}

Z zasady podejście ekologiczne uwalnia podmiot od konieczności utrzymywania złożonych reprezentacji świata. Może on zamiast tego współdziałać ze światem takim, jaki jest, pozwalając sobie na bardziej elastyczne i szybsze odpowiedzi $\mathrm{w}$ dynamicznym środowisku, w którym podmiot jest $\mathrm{w}$ stanie nauczyć się afordancji swojego otoczenia, rozpoznając je z pierwszej ręki. 
Istnieje obecnie znacząca liczba badań, w których ekologiczne i oparte na afordancjach podejścia z powodzeniem stosuje się do rozwiązywania problemów stojących przed robotami. Podczas gdy psychologowie i badacze sztucznej inteligencji nie zawsze zgadzają się w sprawie szczegółów dotyczących implementacji, mają wspólny cel, jakim jest lepsze zrozumienie systemów podmiot-środowisko.

Niemniej nadal istnieją znaczące różnice. Chcielibyśmy, by zostały one rozważone. W szczególności jeśli nie da się rozwiązać problemu z percepcją bezpośrednią, to uważamy, że trzeba zrezygnować z prób ścisłego pogodzenia podejścia Gibsona ze znaczną częścią obecnych prac w AI i robotyce, które zależą od reprezentacji wewnętrznych. Wtedy albo afordancje należałoby zdefiniować tak wąsko, aby dopuścić tylko zachowania, które mogą bazować na bardzo prostych mechanizmach, takich jak strumień optyczny, albo tak szeroko, aby dać badaczom trochę wskazówek praktycznych. Pomimo opisanych problemów mamy nadzieję, że podejście ekologiczne w dalszym ciągu będzie wzbogacało projektowanie sztucznych podmiotów, a rosnący dialog między psychologami a inżynierami AI przyczyni się do odniesienia sukcesu w obu dziedzinach.

Zachęty dodaje nam pojawienie się w ostatnich latach zwiększonego zainteresowania robotyką opartą o afordancje. Co więcej, w przypadku wielu projektowanych podmiotów wykraczamy poza problemy prostej nawigacji i unikania przeszkód. Stosujemy podejście ekologiczne w projektowaniu robotów, które są zdolne do modyfikowania środowiska, z którym wchodzą w interakcje. Przewidujemy, że projektowanie, w którym wykorzystuje się afordancje, będzie zyskiwało na znaczeniu wraz $\mathrm{z}$ rozwojem robotów przejawiających coraz bardziej złożone zachowania.

\section{Literatura}

Agre, P.E. i Chapman, D. 1987. Pengi: Implementation of a Theory of Activity. Artificial Intelligence.

Arkin, R.C. 1990. The Impact of Cybernetics on the Design of a Mobile Robot System: A Case Study. IEEE Transactions on Systems, Man and Cybernetics, 20 (6).

Atil, I., Dag, N., Kalkan, S., i Şahin, E. 2010. Affordances and emergence of concepts. Proceedings of the Tenth International Conference on Epigenetic Robotics: 11-18.

Bacchus, F., Halpern, J.Y. i Levesque, H.J. 1999. Reasoning about noisy sensors and effectors in the situation calculus. Artificial Intelligence, 111 (1): 171-208.

Ballard, D.H. 1991. Animate vision. Artificial Intelligence, 48 (1): 57-86.

Brooks, R.A. 1997. From earwigs to humans. Robotics and Autonomous Systems, 20: 291-304.

Brooks, R.A. i Stein, L.A. 1994. Building brains for bodies. Autonomous Robots. 
Brooks, R.A. 1990. Elephants don’t play chess. Robotics and Autonomous Systems, 6 (12): 3-15.

Brooks, R.A. 1986. A robust layered control system for a mobile robot. Robotics and Automation, 2 (1): 14-23.

Çakmak, M., Dogar, M., Ugur, E., i Şahin E. 2007. Affordances as a framework for robot control. Proceedings of The 7th International Conference on Epigenetic Robotics.

Chapman, D. 1991. Vision, instruction, and action. Cambridge, MA, USA: MIT Press.

Chemero, A. 2003. An Outline of a Theory of Affordances. Ecological Psychology, 15 (2): 181-195.

Chemero, A. i Turvey, M. 2007. Gibsonian Affordances for Roboticists. Adaptive Behavior, 15 (4): 473.

Cos-Aguilera, I., Canamero, L., \& Hayes, G. 2003a. Learning object functionalities in the context of behavior selection. Proceedings of the 3rd Conference Towards Intelligent Mobile Robotics: 9-14.

Cos-Aguilera, I., Canamero, L., i Hayes, G. M. 2003b. Motivation-driven learning of object affordances: First experiments using a simulated khepera robot. Proceedings of the 9th International Conference in Cognitive Modelling (ICCM'03), 4.

Cos-Aguilera, I., Hayes, G., i Canamero, L. 2004. Using a SOFM to learn object affordances. Proceedings of the 5th Workshop of Physical Agents.

Dag, N., Atıl, I., Kalkan, S., i Şahin, E. 2010. Learning affordances for categorizing objects and their properties. International Conference on Pattern Recognition.

Detry, R., Başeski, E., Popović, M., Touati, Y., Krüger, N., Kroemer, O., Peters, J. i Piater, J. 2009. Learning object-specific grasp affordance densities. IEEE 8th International Conference on Development and Learning: 1-7.

Detry, R., Başeski, E., Popović, M., Touati, Y., Krüger, N., Kroemer, O., Peters, J. i Piater, J. 2010. Learning continuous grasp affordances by sensorimotor exploration. From Motor Learning to Interaction Learning in Robots: 451-465.

Detry, R., Kraft, D., Kroemer, O., Bodenhagen, L., Peters, J., Krüger, N., i Piater, J. 2011. Learning grasp affordance densities. Paladyn. Journal of Behavioral Robotics, 2(1): $1-17$.

Duchon, A., Kaelbling, L. i Warren, W. 1998. Ecological robotics. Adaptive Behavior, 6 (3-4): 473-507.

Erdemir, E., Frankel, C. B., Kawamura, K., Gordon, S. M., Thornton, S., i Ulutas, B. 2008a. Towards a cognitive robot that uses internal rehearsal to learn affordance relations. Intelligent Robots and Systems: 2016-2021.

Erdemir, E., Frankel, C. B., Thornton, S., Ulutas, B., i Kawamura, K. 2008b. A robot rehearses internally and learns an affordance relation. 7th IEEE International Conference on Development and Learning: 298-303.

Fikes, R.E., Hart, P.E. i Nilsson, N.J. 1972. Learning and executing generalized robot plans. Artificial intelligence, 3: 251-288. 
Fitzpatrick, P., Metta, G., Natale, L., Rao, S., i Sandini, G. 2003. Learning about objects through action-initial steps towards artificial cognition. IEEE International Conference on Robotics and Automation, 3: 3140-3145.

Fodor, J. i Pylyshyn, Z. 1981. How direct is visual perception? Some reflections on Gibson’s ecological approach. Cognition, 9(2): 139-196.

Fritz, G., Paletta, L., Breithaupt, R., Rome, E., i Dorffner, G. 2006a. Learning predictive features in affordance based robotic perception systems. IEEE/RSJ International Conference on Intelligent Robots and Systems.

Fritz, G., Paletta, L., Kumar, M., Dorffner, G., Breithaupt, R., i Rome, E. 2006b. Visual learning of affordance based cues. From Animals to Animats 9: 52-64.

Gat, E. 1998. On three-layer architectures. Artificial intelligence and mobile robots: case studies of successful robot systems: 195-210.

Gibson, J.J. 1979. The Ecological Approach to Visual Perception. Houghton Mifflin.

Gibson, J.J. 1966. The Senses Considered as Perceptual Systems. Boston, MA: Houghton Mifflin.

Gould, S. i in. 2007. Peripheral-foveal vision for real-time object recognition and tracking in video. Proceedings of the Twentieth International Joint Conference on Artificial Intelligence (IJCAI-07).

Griffith, S., Sukhoy, V., Wegter, T., i Stoytchev, A. 2012a. Object Categorization in the Sink: Learning Behavior-Grounded Object Categories with Water. Proceedings of the 2012 ICRA Workshop on Semantic Perception, Mapping and Exploration.

Griffith, S., Sinapov, J., Sukhoy, V., i Stoytchev, A. 2012. A Behavior-Grounded Approach to Forming Object Categories: Separating Containers From Noncontainers. IEEE Transactions on Autonomous Mental Development, 4 (1): 54-69.

Guerin, F., Kruger, N. i Kraft, D. 2012. A Survey of the Ontogeny of Tool Use: from Sensorimotor Experience to Planning. IEEE Transactions on Autonomous Mental Development.

Gyr, J. 1972. Is a theory of direct visual perception adequate? Psychological Bulletin, 77 (4): 246-61.

Heft, H. 2003. Affordances, Dynamic Experience, and the Challenge of Reification. Ecological Psychology, 15 (2): 149-180.

Horton, T., Williams, L., Mu, W. i St. Amant, R. 2008. Visual affordances and symmetries in canis habilis: A progress report. AAAI Fall Symposium Technical Report.

Horton, T. 2011. A partial contour similarity-based approach to visual affordances in habile agents. Ph.D. thesis, North Carolina State University.

Jacquet, P. O., Chambon, V., Borghi, A. M., i Tessari, A. 2012. Object Affordances Tune Observers' Prior Expectations about Tool-Use Behaviors. PloS one, 7(6): e39629.

Jain, R., i Inamura, T. 2011. Learning of Tool Affordances for autonomous tool manipulation. IEEE/SICE International Symposium on System Integration: 814-819.

Jones, K. 2003. What Is an Affordance? Ecological Psychology, 15 (2): 107-114. 
Kemp, C. C., i Edsinger, A. 2006. Robot manipulation of human tools: Autonomous detection and control of task relevant features. Proceedings of the Fifth International Conference on Development and Learning.

Kirlik, A. 2004. On Stoffregen's Definition of Affordances. Ecological Psychology, 16 (1): 73-77.

Kraft, D., Detry, R., Pugeault, N., Başeski, E., Piater, J., i Krüger, N. 2009. Learning objects and grasp affordances through autonomous exploration.Computer Vision Systems: $235-244$.

Kuniyoshi, Y., Kita, N., Suehiro, T. i Rougeaux, S. 1996. Active stereo vision system with foveated wide angle lenses. Recent developments in computer vision, 191-200.

Marr, D. 1982. Vision: A Computational Investigation into the Human Representation and Processing of Visual Information. New York, NY, USA: Henry Holt and Co., Inc.

Matarić, M.J. 2002. Situated Robotics. Ed. L. Nadel. Encyclopedia of Cognitive Science: Nature Publishing Group.

Matarić, M.J. 1997. Behavior-Based Control: Examples from Navigation, Learning and Group Behavior. Journal of Experimental and Theoretical Artificial Intelligence, 9 (23): 323-336.

Matarić, M.J. 1994. Interaction and Intelligent Behavior. Ph.D. thesis, Massachusetts Institute of Technology.

Maes, P., red. 1991. Designing autonomous agents: Theory and practice from biology to engineering and back. MIT Press.

Michaels, C. 2003. Affordances: Four Points of Debate. Ecological Psychology, 15 (2): 135-148.

Michaels, C. i Carello, C. 1981. Direct perception. Englewood Cliffs, NJ: Prentice-Hall.

Murphy, R.R. 1999. Case Studies of Applying Gibson's Ecological Approach to Mobile Robots. IEEE Transactions on Systems, Man and Cybernetics, Part A: Systems and Humans, 29 (1): 105-111.

Newell, A. i Simon, H. 1963. GPS: A program that simulates human thought. Feigenbaum \& Feldman, eds. Computers and Thought. New York: McGraw-Hill.

Norman, D. 1999. Affordance, conventions, and design. Interactions, 6 (3): 38-41.

Norman, D. 1988. The psychology of everyday things. New York: Basic Books.

Rome, E., Paletta, L., Şahin, E., Dorffner, G., Hertzberg, J., Breithaupt, R., Fritz, G., Irran, J., Kintzler, F., Lörken, C., May, S. i Uğur, E. 2008. The MACS project: an approach to affordance-inspired robot control. Towards affordance-based robot control: 173-210.

Sacerdoti, E.D. 1974. Planning in a hierarchy of abstraction spaces. Artificial intelligence, 5 (2): 115-135.

Şahin, E., Çakmak, M., Doğar, M., Uğur, E. i Üçoluk, G. 2007. To Afford or Not to Afford: A New Formalization of Affordances Toward Affordance-Based Robot Control. Adaptive Behavior, 15 (4): 447. 
Scassellati, B. 1999. A binocular, foveated active vision system. Technical report, DTIC Document.

Sinapov, J., i Stoytchev, A. 2007. Learning and generalization of behavior-grounded tool affordances. IEEE 6th International Conference on Development and Learning: 19-24.

Sinapov, J. i Stoytchev, A. 2008. Detecting the functional similarities between tools using a hierarchical representation of outcomes. 7th IEEE International Conference on Development and Learning, 2008: 91-96.

Srinivasan, M. i Zhang, S. 2004. Visual motor computations in insects. Annual Review of Neuroscience, 27: 679-696.

Stentz, A. 1995. The focussed $\mathrm{D}^{*}$ algorithm for real-time replanning. Proceedings of International Joint Conference on Artificial Intelligence, 14: 1652-1659.

Stoffregen, T. 2004. Breadth and Limits of the Affordance Concept. Ecological Psychology, 16 (1): 79-85.

Stoffregen, T. 2003. Affordances as Properties of the Animal-Environment System. Ecological Psychology, 15 (2): 115-134.

Stoytchev, A. 2008. Learning the Affordances of Tools using a Behavior-Grounded Approach. E. Rome et al., eds. Affordance-Based Robot Control, Springer Lecture Notes in Artificial Intelligence: 140-158.

Stoytchev, A. 2005. Behavior-grounded representation of tool affordances. Proceedings of IEEE International Conference on Robotics and Automation.

Sun, J., Moore, J., Bobick, A. i Rehg, J. 2010. Learning visual object categories for robot affordance prediction. The International Journal of Robotics Research, 29 (2-3): 174197.

Ugur, E., Oztop, E., i Şahin, E. 2011. Goal emulation and planning in perceptual space using learned affordances. Robotics and Autonomous Systems, 59(7), 580-595.

Ugur, E., Şahin, E. i Oztop, E. 2009. Predicting future object states using learned affordances. In Computer and Information Sciences, 2009. ISCIS 2009. 24th International Symposium on, 415-419. IEEE.

Ugur, E. i Şahin, E. 2010. Traversability: A case study for learning and perceiving affordances in robots. Adaptive Behavior, 18 (3-4): 258-284.

Ullman, S. 1980. Against direct perception. Behavioral and Brain Sciences, 3 (373-415): 200.

Vera, A. i Simon, H. 1993. Situated action: A symbolic interpretation. Cognitive Science, 17 (1): 7-48.

Wood, A., Horton, T. i St. Amant, R. 2005. Effective tool use in a habile agent. Systems and Information Engineering Design Symposium, 2005 IEEE, 75-81.

Yürüten, O., Uyanık, K., Çalışkan, Y., Bozcuoğlu, A., Şahin, E., i Kalkan, S. 2012. Learning Adjectives and Nouns from Affordances on the iCub Humanoid Robot. From Animals to Animats 12: 330-340. 
Zilberstein, S. i Russell, S.J. 1993. Anytime sensing, planning and action: A practical model for robot control. W: Proceedings of International Joint Conference on Artificial Intelligence, 13: 1402-1402.

\begin{abstract}
In this paper, we consider the influence of Gibson's affordance theory on the design of robotic agents. Affordance theory (and the ecological approach to agent design in general) has in many cases contributed to the development of successful robotic systems; we provide a brief survey of AI research in this area. However, there remain significant issues that complicate discussions on this topic, particularly in the exchange of ideas between researchers in artificial intelligence and ecological psychology. We identify some of these issues, specifically the lack of a generally accepted definition of "affordance" and fundamental differences in the current approaches taken in AI and ecological psychology. While we consider reconciliation between these fields to be possible and mutually beneficial, it will require some flexibility on the issue of direct perception.
\end{abstract}

Keywords: affordance; artificial intelligence; ecological psychology; Gibson; robotics. 